\title{
Study of foetomaternal outcome of antepartum haemorrhage in pregnancy
}

\section{Siddhartha Majumder*, Parul T. Shah, Kruti J. Deliwala, Rina V. Patel, Anuradha Madiya}

Department of Obstetrics \& Gynaecology, Sheth V.S. General Hospital, Ahmedabad,Gujarat, India

Received: 29 September 2015

Accepted: 29 October 2015

\section{*Correspondence:}

Dr. Siddhartha Majumder

E-mail: siddharthamajumder5@gmail.com

Copyright: (C) the author(s), publisher and licensee Medip Academy. This is an open-access article distributed under the terms of the Creative Commons Attribution Non-Commercial License, which permits unrestricted non-commercial use, distribution, and reproduction in any medium, provided the original work is properly cited.

\section{ABSTRACT}

Background: Any bleeding from the genital tract during pregnancy, after the period of viability until the delivery of the fetus (end of second stage), is defined as antepartum hemorrhage. The World Health Authority defines antepartum haemorrhage as bleeding after 28 weeks of pregnancy. At the country level, the two countries that accounted for one third of all global maternal deaths are India at $17 \%$ and Nigeria at $14 \%$ in 2013. Maternal health and newborn health care are closely linked. Almost 3 million newborn babies die every year and an additional 2.6 million babies are stillborn. With improvement in medical facilities, early diagnosis, availability of blood transfusion, good anesthesia, proper management of shock and other complication of pregnancy along with liberalization of caesarean section, the rate of maternal morbidity and mortality is gradually on the decline.

Methods:

This is a prospective study of 100 cases of APH admitted during the period of May 2014 to April 2015 at a tertiary care hospital. Patients in third trimester of pregnancy with APH have been included in this study.

Results: In present study incidence of APH is 3.8\% and of the 100 sample cases 66 cases were of placenta previa and 34 cases were of abruptio placenta. In the present study $64 \%$ were emergency cases. Incidence of APH was $60 \%$ in age group 21-30 years of which $70 \%$ cases were noted with parity of $>2$. Ultrasonography was very much helpful in diagnosing placenta previa (93.9\%), while most cases $(76.4 \%)$ of abruptio placenta were diagnosed clinically. At the time of admission $75 \%$ patients were anaemic and many required blood transfusion. The perinatal mortality rate of abruptio placenta is $44.1 \%$ and placenta previa is $12.1 \%$. Perinatal loss is $22.5 \%$ for up to foetus weighing $2 \mathrm{~kg}$, $18.7 \%$ for foetus weighing between $2.1-2.5 \mathrm{~kg}$ and $27.02 \%$ for those $\geq 2.6 \mathrm{~kg}$.

Conclusions: Educating pregnant mothers about the importance of antenatal care and easy accessibility to quality antenatal services would go a long way in bringing down the maternal and perinatal morbidity and mortality related with antepartum haemorrhage. The morbidity associated with placenta previa can be reduced by detecting the condition in the antenatal period by ultrasound, before it becomes symptomatic. Intensive family planning program and awareness of small family norm helps in decreasing cases of APH in relation with age and parity. Efforts should be made to reduce the rates of operative deliveries, because there is a greater likelihood of placenta previa in a scarred uterus. There is a lot of scope on further research in the field of APH for further reduction in foetal and maternal morbidity and mortality.

Keywords: Antepartum haemorrhage, Placenta previa, Abruptio placenta, Perinatal mortality 


\section{INTRODUCTION}

Any bleeding from the genital tract during pregnancy, after the period of viability until the delivery of the fetus (end of second stage) is defined as antepartum haemorrhage. The World Health Authority defines antepartum haemorrhage as bleeding after 28 weeks of pregnancy. Uterine bleeding coming from above the cervix is concerning. It may follow some separation of a placenta previa implanted in the immediate vicinity of the cervical canal, or it may be from a placental abruption or uterine tear. ${ }^{1,2}$

At the country level, the two countries that accounted for one third of all global maternal deaths are India at 17\% and Nigeria at $14 \%$ in $2013 .^{3}$ The major complications that account for nearly $75 \%$ of all maternal deaths are severe bleeding (mostly bleeding after childbirth), infections (usually after child birth), high blood pressure during pregnancy (pre-eclampsia and eclampsia), complications from delivery and unsafe abortion. ${ }^{4}$ Maternal health and newborn health care are closely linked. Almost 3 million newborn babies die every year and an additional 2.6 million babies are stillborn. ${ }^{5,6}$

There has been a gratifying decline in maternal and foetal morbidity and mortality in cases of antepartum haemorrhage because of improvement in antepartum, intrapartum and postpartum care in recent years. With improvement in medical facilities, early diagnosis, availability of blood transfusion, good anaesthesia, proper management of shock and other complication of pregnancy along with liberalisation of caesarean section, the rate of maternal morbidity and mortality is gradually on the decline.

This is an analytical study of cases of antepartum haemorrhage attending our hospital with their maternal and foetal outcome.

\section{METHODS}

This was a prospective study of 100 cases of APH admitted during the period of May 2014 to April 2015 at a tertiary care hospital. Patients of third trimester pregnancy with APH had been included in this study.

\section{RESULTS}

Total 8568 deliveries were conducted during this period of which 326 cases were of APH. The incidence of APH is $3.8 \%$.

Table 1 shows the maternal characteristics. Majority of the patients $(64 \%)$ were unregistered and referred to our tertiary care hospital. APH is more common(60\%) in 2130 years combined age group which is the most common reproductive age group. Incidence of APH is more in multigravida (88\%). Placenta previa occurs mostly between 33-36 weeks gestation (47\%) and abruption placenta occurs mostly near term $(15 \%)$.

Table 1: Maternal characteristics.

\begin{tabular}{|c|c|c|c|}
\hline & $\begin{array}{l}\text { Placenta } \\
\text { previa }\end{array}$ & $\begin{array}{l}\text { Abruptio } \\
\text { placenta }\end{array}$ & Total \\
\hline \multicolumn{4}{|c|}{ Booking status } \\
\hline Registered & 21 & 15 & 36 \\
\hline Unregistered & 45 & 19 & 64 \\
\hline \multicolumn{4}{|l|}{ Age in years } \\
\hline$\leq 20$ & 10 & 1 & 11 \\
\hline $21-25$ & 21 & 5 & 26 \\
\hline $26-30$ & 22 & 12 & 34 \\
\hline $31-35$ & 10 & 15 & 25 \\
\hline$\geq 36$ & 3 & 1 & 4 \\
\hline \multicolumn{4}{|l|}{ Parity } \\
\hline 1 & 12 & 6 & 18 \\
\hline $2-4$ & 48 & 23 & 71 \\
\hline$\geq 5$ & 6 & 5 & 11 \\
\hline \multicolumn{4}{|c|}{ Gestational age (weeks) } \\
\hline $28-32$ & 17 & 5 & 22 \\
\hline $33-36 \mathrm{~d}$ & 47 & 14 & 61 \\
\hline $37-40$ & 2 & 15 & 17 \\
\hline
\end{tabular}

Table 2: Associated obstetrical conditions.

\begin{tabular}{|lccl|}
\hline Malpresentation & $\begin{array}{l}\text { Placenta } \\
\text { previa }\end{array}$ & $\begin{array}{c}\text { Abruptio } \\
\text { placenta }\end{array}$ & Total \\
\hline Anaemia & 51 & 2 & 9 \\
\hline Pre-eclampsia & 4 & 18 & 75 \\
\hline Previous curettage & 8 & 3 & 22 \\
\hline $\begin{array}{l}\text { Previous caesarean } \\
\text { section }\end{array}$ & 12 & 3 & 11 \\
\hline
\end{tabular}

Table 3: Maternal and perinatal complications and management.

\begin{tabular}{|llll|}
\hline & $\begin{array}{l}\text { Placenta } \\
\text { previa }\end{array}$ & $\begin{array}{l}\text { Abruptio } \\
\text { placenta }\end{array}$ & Total \\
\hline USG Diagnosis & 62 & 8 & 80 \\
\hline $\begin{array}{l}\text { Clinical } \\
\text { Diagnosis }\end{array}$ & 4 & 26 & 20 \\
\hline PPH & 2 & - & 2 \\
\hline DIC & - & 2 & 2 \\
\hline Rupture Uterus & 1 & - & 1 \\
\hline $\begin{array}{l}\text { Retained } \\
\text { Placenta }\end{array}$ & - & 1 & 1 \\
\hline $\begin{array}{l}\text { Couvelaire } \\
\text { Uterus }\end{array}$ & - & 2 & 2 \\
\hline $\begin{array}{l}\text { Blood } \\
\text { Transfusion }(\geq 5 \\
\text { units) }\end{array}$ & 3 & 2 & 5 \\
\hline $\begin{array}{l}\text { Caesarean } \\
\text { Section }\end{array}$ & 66 & 19 & 85 \\
\hline Maternal death & - & - & - \\
\hline
\end{tabular}


Table 2 shows the associated obstetric conditions. In present study $10.6 \%$ of patients of placenta previa and $5.8 \%$ of abruptio placenta had abnormal presentation. Most of the patients $(75 \%)$ were anaemic $(<10 \mathrm{gm} \%)$ at the time of admission and $22 \%$ of the patients had preeclampsia. Among patients with placenta previa $8 \%$ had previous curettage and $12 \%$ had previous caesarean sections.

Table 3 shows the maternal and perinatal complication and management of APH. While $80 \%$ of the diagnoses were made by Ultrasonography, the rest $20 \%$ of the diagnoses were made clinically. Blood transfusion was required in many patients and $\geq 5$ units were given in 3 cases of placenta previa and 2 cases of abruption placenta. In abruptio placenta the rate of caesarean section was $55.8 \%$ while in all cases of placenta previa the mode of delivery was caesarean section. There was no maternal mortality.

Table 4 shows the perinatal outcome wherein the perinatal mortality rate of abruptio placenta is $44.1 \%$ and placenta previa is $12.1 \%$. Perinatal loss is $22.5 \%$ for up to $2 \mathrm{~kg}$ weighing foetuses, $18.7 \%$ for foetuses weighing 2.1 $2.5 \mathrm{~kg}$ and $27.02 \%$ for those $\geq 2.6 \mathrm{~kg}$.

\section{DISCUSSION}

In this present study the incidence of APH is 3.8\%, which is more than the incidence of $2.53 \%$ as per the analytical study on perinatal morbidity and mortality in APH by the study done by Arora and co-workers from Pondicherry. ${ }^{7}$

Table 4: Perinatal outcome in relation with birth weight.

\begin{tabular}{|c|c|c|c|c|c|c|}
\hline \multirow{3}{*}{$\begin{array}{l}\text { Perinatal } \\
\text { outcome }\end{array}$} & \multicolumn{6}{|c|}{ Birth weight } \\
\hline & $2 \mathrm{~kg}$ & & $2.1-2.5 \mathrm{~kg}$ & & $>2.6 \mathrm{~kg}$ & \\
\hline & $\begin{array}{l}\text { Placenta } \\
\text { previa }\end{array}$ & $\begin{array}{l}\text { Abruptio } \\
\text { placenta }\end{array}$ & $\begin{array}{l}\text { Placenta } \\
\text { previa }\end{array}$ & $\begin{array}{l}\text { Abruptio } \\
\text { placenta }\end{array}$ & $\begin{array}{l}\text { Placenta } \\
\text { previa }\end{array}$ & $\begin{array}{l}\text { Abruptio } \\
\text { placenta }\end{array}$ \\
\hline Live birth & 16 & 8 & 22 & 4 & 20 & 7 \\
\hline IUD & 4 & 2 & 2 & 3 & 1 & 9 \\
\hline Still Birth & 1 & - & - & 1 & - & - \\
\hline Total & 21 & 10 & 24 & 8 & 21 & 16 \\
\hline $\begin{array}{l}\text { Perinatal } \\
\text { mortality rate }\end{array}$ & $22.5 \%$ & & $18.7 \%$ & & $27.02 \%$ & \\
\hline
\end{tabular}

In present study majority of cases of antepartum haemorrhage were of unregistered emergency patients (64\%). Among unregistered cases those patients who do not have regular antenatal visits will have a higher incidence of placenta previa and associated complications as they have been referred to our tertiary care hospital. Early marriage and repeated pregnancies at short intervals maybe responsible for $60 \%$ of cases of antepartum haemorrhage in the combined age group of 21-30 years age group and $88 \%$ occurring in multigravida. Frequency of placenta previa increases with maternal age (Biro, 2012). Present study shows that a multigravida is more prone to APH $(88 \%)$ than a primigravida which is comparable to study of S Singhal (2013) who also reported that incidence of APH increases in multigravida. Patients of placenta previa presenting with a bout of bleeding are more commonly at 33-36 weeks of gestation resulting in preterm delivery. However abruptio placenta is more common in pregnancy around term. Abnormal presentation was seen in $10.6 \%$ patients of placenta praevia and $5.8 \%$ patients of abruptio placenta. Raksha et al, found foetal malpresentation to be $23 \%$ in placenta previa and $11 \%$ in abruption placenta. Anaemia was found in $75 \%$ of patients and pre-eclampsia in $22 \%$ of patients which is comparable to S Singhal (2013). A definite association of placenta previa following curettage $(12.12 \%)$ or caesarean section $(18.18 \%)$ was present. The cumulative risks for placenta previa that accrue with the increasing number of caesarean deliveries are extraordinary. Ultrasonography was a useful mode of diagnosis in cases of placenta previa; however abruptio placenta was more frequently diagnosed by clinical examination. Caesarean section is necessary practically in all cases of placenta previa and higher incidence of LSCS (19\%) in cases of APH is mainly to reduce maternal and foetal mortality due to haemorrhage. Perinatal mortality in $44.1 \%$ cases of abruptio placenta and $12.1 \%$ cases of placenta previa which is lower than $\mathrm{S}$ Singhal (2013) study. This is probably due to early diagnosis and timely intervention and having a wellequipped NICU. Perinatal loss is higher in babies with low birth weight and higher number of cases of abruption during 33-37 weeks explains high perinatal mortality rate in babies with birth weight $\geq 2.6 \mathrm{~kg}$. $28-14$ 


\section{CONCLUSION}

Antepartum haemorrhage is a grave and potentially life threatening condition for mother and foetus which tests the limits of even the best equipped obstetrical and neonatal units. Educating the pregnant mother about the importance of antenatal care and easy accessibility to quality antenatal services would go a long way in bringing down the maternal and perinatal morbidity and mortality related with antepartum haemorrhage. There are no reliable predictors of the timing in pregnancy at which placental abruption may happen but when diagnosed active team management should be done. Following placental abruption a practice of elective delivery after reaching foetal maturity in subsequent pregnancies is reasonable in view of recurrence. The morbidity associated with placenta previa can be reduced by detecting the condition in the antenatal period by ultrasound before it becomes symptomatic. Intensive family planning programme and awareness of small family norm helps in decreasing cases of APH in relation with age and parity. Efforts should be made to reduce the rate of operative deliveries, because there is a greater likelihood of placenta previa in a scarred uterus and risk of placenta accreta and recurrence also increases in subsequent pregnancies. However caesarean delivery is performed in almost all patients of placenta previa. There is a lot of scope for further research in the field of APH in order to reduce foetal and maternal morbidity and mortality.

Funding: No funding sources

Conflict of interest: None declared

Ethical approval: The study was approved by the Institutional Ethics Committee

\section{REFERENCES}

1. Ian Donald's Practical Obstetric Problems; $7^{\text {th }}$ Edition.2014:315.

2. Williams Obstetrics :F.Gary Cunningham, Kenneth J.Leveno, Steven L.Bloom, Catherine Y.Spong, Jodi S, Dashe, Barbara L.Hoffman, Brian M.Casey, Jeanne S.Sheffield. 24th Edition:783,801,803.
3. WHO 2014. Trends in maternal mortality: 1990 to 2013 Estimates by WHO, UNICEF, UNFPA, The World Bank and the United Nations Population Division.

4. Say L et al. Global Causes of Maternal Death: A WHO Systematic Analysis. Lancet. 2014; 6(1):e32333.

5. UNICEF, WHO, the World Bank, United Nations Population Division. The Inter-agency Group for Child Mortality Estimation (UN IGME). Levels and Trends in Child Mortality. Report 2013. New York, USA, UNICEF, 2013.

6. Cousens S, Blencowe H, Stanton C, Chou D, Ahmed $\mathrm{S}$, Steinhardt L, et al. National, regional, and worldwide estimates of stillbirth rates in 2009 with trends since 1995: a systematic analysis. Lancet. 2011;377(9774):1319-30.

7. Arora R, Devi U, Majumdar K. Perinatal morbidity and mortality in antepartum haemorrhage. J Obstet Gynaecol India. 2001;51(3):102.

8. Biro MA, Davey MA, Carolan M, et al. Advanced maternal age and obstetric morbidity for women giving birth in Victoria, Australia: a populationbased study. Aust NZJ Obstet Gynaecol. 2012;52(3):229-34.

9. S Singhal, Nymphaea, S Nanda. Maternal and Perinatal outcome in Antepartum haemorrhage: A study at tertiary care referral institute .The Internet Journal of Gynaecology and Obstetrics: 2013; 9(2).

10. Mukherjee J, Saha S, et al. A 5 year review of severe placental abruption. J Obstet Gynecol Ind. 2003;53(2):149-52.

11. Raksha A, Umad, Kingshuk ML, et al. Perinatal mortality and morbidity in APH, J. Obstet Gynecol Ind. 2001;51(3):102-4.

Cite this article as: Majumder S, Shah PT, Deliwala KJ , Patel RV, Madiya A. Study of foetal and maternal outcome of antepartum haemorrhage in pregnancy. Int J Reprod Contracept Obstet Gynecol 2015;4:1936-9. 